\title{
Sustaining Employees through Co-worker and Supervisor Support: Evidence from Thailand
}

\author{
Kua Wongboonsin, Pitichai Dejprasertsri, Tanasak Krabuanrat,* Siriyupa \\ Roongrerngsuke, Sabin Srivannaboon and Piyachart Phiromswad
}

\begin{abstract}
Manuscript type: Research paper

Research aims: This study aims to examine the effects of perceived co-worker and supervisor support on employees' intention to quit in the food and beverage industry in Thailand.

Design/Methodology/Approach: A total of 322 entry-level employees were recruited from one of Thailand's largest food and beverage company as respondents for our survey. Data were then analysed using the OLS regression.
\end{abstract}

* Corresponding author: Tanasak Krabuanrat is an Assistant Professor at the Department of Operations \& Technology, Sasin School of Management, Chulalongkorn University, Thailand. Email: tanasak.krabuanrat@sasin.edu

Kua Wongboonsin is a Professor and Senior Researcher at the Sasin School of Management, Chulalongkorn University, Thailand. Email: kua.wongboonsin@sasin.edu;

Pitichai Dejprasertsri is the Human Resource Manager at the Coffee Club Thailand. Email: pitichai.dejprasertsri@sasin.edu

Siriyupa Roongrerngsuke is an Associate Professor at the Sasin School of Management, Chulalongkorn University, Thailand. Email: siriyupa.roongrerngsuke@sasin.edu

Sabin Srivannaboon is an Assistant Professor at the Department of Operations and Technology, Sasin School of Management, Chulalongkorn University, Thailand. Email: sabin. srivannaboon@sasin.edu

Piyachart Phiromswad is an Assistant Professor at the Finance Department, Sasin School of Management, Chulalongkorn University, Thailand. Email: piyachart.phiromswad@sasin.edu

This research was supported by the Thailand Research Fund (TRF) under the TRF Senior Research Scholar No. RTA5780011 and Chulalongkorn University. The opinion reflected in this paper are those of the author(s) and not of the Thailand Research Fund (TRF) nor Chulalongkorn University.

https://doi.org/10.22452/ajba.vol11no2.6 
Research findings: Our results highlight that workplace social support as indicated by existing literature were predominantly conducted in Western countries and these were found to be inapplicable in the Thai context. Our study also highlights some inconsistent results between the different age group of workers.

Theoretical contributions/Originality: Our study expands on previous literature by making empirical contributions from the perspective of Thailand. As a collectivistic and feminine society, Thailand carries results that are different from the West. Our study also makes contributions by providing evidence drawn from the different age group perspective.

Practitioner/Policy implications: Companies in Asian countries should reconsider their strategies in retaining workers. Our results offer strategies that are guided by the outcome generated from an Asian context which is highly different from the Western context.

Research limitation/Implications: Since this study only focused on employees from one company, the generalisability of our results may be restricted.

Keywords: Co-Worker Support, Supervisor Support, Intention to Quit, Employee Retention, Employment Sustainment

JEL Classification: M12, M54, M59

\section{Introduction}

Employee retention began to manifest itself in the early 1900s and today, it has become a critical workforce challenge for many companies. The sharp decline of the working population has further aggravated the employee retention issue. According to the World Population Prospects 2015 forecasted by the United Nations, the fraction of the working age population (defined as population aged 15-64) for several countries in Asia are projected to decline sharply between 2015-2050 (e.g. from 72.6 per cent to 59.7 per cent for China; 73.1 per cent to 53.2 per cent for South Korea; 72.8 per cent to 55.4 per cent for Singapore; 70.2 per cent to 61.6 per cent for Vietnam; 71.4 per cent to 58.0 per cent for Thailand). This issue is compounded by Thailand's fast transition from its ageing society (defined as a population with proportion of seniors 65+ years old over 7 per cent) to an aged society (defined as a population with proportion of seniors $65+$ years old over 14 per cent). The time duration expected for Thailand is 20 years shorter than most developed countries which take 50 to 100 years, with the exception of Japan. To illustrate, it took 69 years for the US to transition from an ageing society to an aged society; 
65 years for Canada and 73 years for Sweden (Arshad \& Bhat, 2013). If this changing atmosphere is not given due attention, many organisations in Thailand may no longer be able to sustain themselves as the long-term health and success of any organisation depends on its ability to retain employees (Presbitero, Roxas, \& Chadee, 2016). Employees are the most vital and dynamic resources of any organisation (Gabčanová, 2011) in today's environment, hence the retention of high-quality workers will be one of the top priorities for most organisations in Thailand. Further, it is important for organisations in Asia in general, and Thailand in particular, to develop more effective retention strategies and practices because of the current high turnover rates, especially among the Millennial cohort (Supeli \& Creed, 2016).

To date, there are extensive research (e.g. Price, 2001; Barak, Nissly, \& Levin, 2001; Chiaburu \& Harrison, 2008; Felps et al., 2009; Scott, Zagenczyk, Schippers, Purvis, \& Cruz, 2014; Chadwick \& Collins, 2015) conducted to explore the influence of social support in the workplace from co-workers and supervisors on other employees' intention to quit. Many studies (e.g., Scott et al., 2014; Chadwick \& Collins, 2015) also found evidence which confirmed that co-workers and supervisors can help to reduce other employees' intention to quit. Different researchers (Beehr, Jex, Stacy, \& Murray, 2000; Semmer et al., 2008; Tews, Michel, \& Ellingson, 2013) have classified such social support in the workplace into two major categories: emotional support (providing support to someone psychologically such as showing empathy or social inclusion) and instrumental support (providing support to someone physically such as physically helping someone to complete a task). Other studies (e.g. Malecki \& Demaray, 2003; Cohen, 2004; Scott et al., 2014; Chadwick \& Collins, 2015) classified such social support at a more refined level comprising empathy, social companionship, encouragement and expressive support, work-related tangible support, work-related informational support, and non-work-related support.

While these studies seem to offer some insights into the value of workplace support, they were mainly conducted in western countries. ${ }^{1}$ Therefore, the findings extracted from these studies may not be generalised to an Asian country such as Thailand due to their cultural, social and economic differences. Unlike the US (where most studies

\footnotetext{
${ }^{1}$ A few exceptions are Newman, Thanacoody and Hui (2011) who examined the influence of supervisor support on the intention to quit of workers in the context of Chinese employees, and Glazer (2006) who examined the influence of social support across cultures.
} 
were conducted), Thailand differs in three cultural dimensions: i) power distance, ii) individualism, and iii) masculinity (Hofstede, 2001). Hence, it is expected that the impact of co-worker and supervisor support in Thailand would be influenced accordingly by these cultural dimensions. While culture is not the primary focus of this study, it is useful to explore whether the social support is applicable and generalisable to a country with a more collectivist culture, such as Thailand. As a developing country, Thailand's social and economic development (e.g. social security system, unemployment benefits, etc.) has not reached the development level experienced by many western countries. It is deemed that this phenomenon could further influence how co-worker and supervisor support can impact on workers' intention to quit.

This paper examines the influence of co-worker and supervisor support on workers' intention to quit (working) in the food and beverage $(\mathrm{F} \& \mathrm{~B})$ industry in Thailand. ${ }^{2}$ The reason for selecting this particular F\&B company was because the F\&B industry appears to be one of the most popular economic segments in Thailand, with an annual growth rate of 14.3 per cent. It will be contributing to a market volume of USD136 million by 2022 (National Food Institute, 2018). This study chooses to focus on co-worker and supervisor support because such workplace support has a high tendency to play an important role in retaining workers in the F\&B service. This is mainly because employees working in a high social intensity environment have been described as those who would typically need social support in the workplace (Barak et al., 2001; Glomb \& Tews, 2004; Chiaburu \& Harrison; 2008; Tews et al., 2013). This paper examines the effect of co-worker and supervisor support through the age factor: i) workers aged 15-24 (referred to as "young workers") and ii) workers aged 25+ (referred to as "older workers"). ${ }^{3}$ It is believed that different age groups may have different responsiveness and expectations of social support. Findings from this study will shed more light on how organisations in Thailand and other countries that share similar cultural values may develop retention strategies that comply with their respective cultural contexts so as to reduce workers' intention to quit.

The remainder of this paper is organised as follows. Section 2 presents the literature review, section 3 discusses the theoretical framework

\footnotetext{
${ }^{2}$ To preserve the confidentiality of the company being surveyed, we cannot reveal the name of this company. However, this company is a listed company in the stock exchange of Thailand with more than 20,000 employees.

${ }^{3}$ We use the definition of young workers from the International Labour Organisation (2010).
} 
and hypotheses development while section 4 highlights the research method. Section 5 reports on the findings and results and section 6 concludes by providing the research implications and conclusion.

\section{Literature Review}

\subsection{Intention to Quit and Employees' Retention}

The terms "intention to leave" and "intention to quit" are often used interchangeably in studies looking at employee turnover. Tett and Meyer (1993) defined intention to leave as a worker's conscious and deliberate willingness to leave the organisation. Sharing the same perception, Cho, Johanson and Guchait (2009) described an employee's intention to quit as his/her voluntary decision to leave the present organisation. Employees' turnover rate has been highlighted as one of the sustainability issues by Global Reporting Initiative (GRI) (GRI, 2002). In 2015, it was reported that organisations lost USD60 million in assets due to employees' turnover (Bureau of Labour Statistics, 2015). In general, turnover is an undesirable event for employers due to the high cost of recruitment, training and the loss of productivity, leading to unsustainable business practices. In comparison, organisations with low employee turnover are more productive and profitable. They could expand their organisations and increase employment opportunities as well as promote positive social change through individuals and community development (Steiner \& Atterton, 2014), thereby leading to sustainability performance. In this context, there is a need for managers to understand the factors that lead to employees' retention as well as the means of effectively managing an organisation.

Many researchers have investigated the reasons causing employees' intention to quit. Sheridan (1992) asserted that job embeddedness, the collection of forces that effect employee retention, is a mediator of the relationship between human resource practices and employees' intention to quit. He explained that job embeddedness fully mediates compensation and growth opportunity whereas it somewhat mediates supervisor support. Nevertheless, it does not mediate training which is related to employees' intention to quit. In addition, reward and compensation are one of the key drivers for employees' intention to stay. However, older generations tend to stay in the same industry whereas Millennials have more interests in trying out new industries. Using 170 retail sales people as samples, Firth, Mellor, Moore, and Loquet (2004) 
investigated the impact of job satisfaction, stress, supervisors' support, locus of control, self-esteem and perceived stressors on workers' intention to quit. Their findings revealed that job dissatisfaction, lack of commitment to the organisation and feelings of stress, essentially trigger workers' intention to quit jobs. However, the problem of job stressors such as work overload, job ambiguity and stress that lead to workers' intention to quit can be reduced through supervisors' support. The study further highlighted that employees' job satisfaction and commitment to the organisation can be increased if the management monitors the workload and the relationship between supervisors and their subordinates effectively. In a similar note, Alén, Banerjee and Gupta (2017) asserted that supportive managers or supervisors act as a driver to their subordinates in generating intrinsic motivation towards their work, which is expected to help reduce workers' intention to quit.

Besides the above studies that had investigated the relationship between the intention to quit and job embeddedness, other researchers (Mathieu, Fabi, Lacoursière, \& Raymond, 2016; Eisenberger, Stinglhamber, Vandenberghe, Sucharski, \& Rhoades, 2002) have attempted to investigate employees' retention. For instance, Hausknecht, Rodda and Howard (2009) proposed that job satisfaction, extrinsic rewards, constituent attachments, organisational commitment and organisational prestige are relevant reasons for employees' retention. The study further proposed that high performers and non-hourly workers valued career advancement opportunities and organisational prestige while extrinsic rewards were more important among low performers and hourly employees. Eisenberger et al. (2002) examined the relationship between employees' perception of supervisor support (PSS), perceived organisational support (POS) and employee turnover. They found that PSS had a higher impact on employee turnover as compared to POS. These findings were attributed to the fact that supervisors engaged more with most employees on a daily basis than the upper level managers. Therefore, they were able to convey positive valuations, care and support better. Being viewed favourably by a supervisor may in turn enhance the socio-emotional needs of the employee. In a more recent study, however, Mathieu et al. (2016) implied that a supervisor having a person-oriented behaviour can impact the workers' intention to quit more than his/her task-oriented leadership behaviour.

Other organisational factors have been proposed to explain older employees' retention and turnover. Shacklock and Brunetto (2011), for example, found that the importance of work and the effects of 
management (e.g. access to flexible working arrangements, supervisor support) served as indicators of older employees' intention to continue working. Among older nurses, it was found that attachment to the work itself was a key driver of older nurses remaining at work. This was coupled by the relationships built with others at work. In another survey conducted of older employees, it was found that the attractiveness of working hours, financial needs, the job itself and job security/stability were significant to older employees' intention to continue working (Radford, Shacklock, \& Bradley, 2012). Other studies (e.g. Kundu \& Gahlawat, 2015) focused on the role of social responsibility practices of the human resource (HR) in reducing turnover rate.

Reviews of the literature show that the issue of employee retention is a perpetual problem. Unresolved, it may lead to companies' inability to sustain themselves. While various factors have been incorporated in previous research, this study is only focusing on the support obtained from co-workers and supervisors. As this study is concentrating on the entry-level position workers only, both the support from co-workers and supervisors are expected to play a vital role. Entry-level positions in the F\&B industry are commonly filled by fresh school leavers or fresh graduates waiting to secure more permanent jobs. As newcomers to the workplace, they may not be familiar with the work processes. In that regard, they may not have had the experience of developing psychological defences to hedge against environmental workplace pressures and challenges (Kang, Gatling, \& Kim, 2015). As such, co-worker's and supervisor's support is highly important in determining their retention.

\subsection{Co-worker and Supervisor Support}

Social support in the workplace can be considered as one of the important factors affecting workers in various aspects such as job satisfaction, productivity and well-being. Cobb (1976) defined social support as an individual's belief that he/she is valued, loved and that his/her well-being is cared for as a component of a social network of mutual obligation. Beehr and McGrath (1992) described co-worker's social support as co-worker's willingness to assist one another (e.g., caring, being friendly, having warm relations, empathy, cooperation, no gossiping and back stabbing, appreciation, respect and support) in carrying out their daily tasks and in reducing troublesome or threatening circumstances. This can help to create a pleasant environment in the workplace (Frone, Russell, \& Cooper, 1997). Bateman (2009) 
claimed that co-worker support is a dimension of social support in the workplace. It refers to assistance received from co-workers when a worker is requested to perform an individual activity, for example, knowledge sharing, encouragement and emotional support.

Among the numerous studies which looked at the relationship between co-worker support and job satisfaction, the study conducted by Babin and Boles (1996) focused on the effect of co-worker support on emotional wellbeing. The results showed that co-worker support decreases strain, role stress and role conflict, hence improves emotional hygiene. Subsequent to that, Ducharme, Knudsen and Roman (2007) classified co-worker support into four categories: affective support (or emotional support, e.g. showing acceptance and caring); informational support (e.g. giving advice or guidance); instrumental support (material assistance); and social companionship (social networking). Using a sample of full-time employees in the US, it was revealed that the impact of instrumental support was stronger than affective support in creating job satisfaction. Both types of support, however, significantly helped to increase overall job satisfaction, which is expected to lead to employee retention. These findings align with the study done by Beehr et al. (2000) who indicated co-worker support as a dimension that would weaken the impact of stress and strain on high social-supported people. In relation to this, Limpanitgul, Robson, Gould-Williams and Lertthaitrakul (2013) discovered that the provision of support from people who share the same work experiences is more effective in helping one to overcome work-related stress as compared to support received from persons in out-groups. In this regard, co-worker support is beneficial in offering emotional support which is also associated with employee retention. Similar findings were documented in more recent research done in Korea (Kwon, 2017) and India (Mutsuddi \& Sinha, 2017). These studies emphasised on the role of closer relationships with co-workers in attracting and retaining human capital in organisations.

Apart from co-worker support, supervisor support is another major influencer of emotional exhaustion reduction and a personal accomplishment promoter. A supervisor is one who structures the work environment and provides information and feedback to employees, thus he/she has a strong impact on each of the team members. From the sociological perspective, Yoon and Thye (2000) posited that support from co-workers and the larger organisation leads to higher supervisor support. Employees with positive dispositions do not necessarily receive more supervisor support in the Korean context. Supervisors in Korea 
viewed employee's positive disposition as a kind of tactical strategy, spurred on by feelings of inadequacy, rather than by employees' internal feature. Without a broader support from co-workers and top management, the positivity effect may lead to lower supervisor support. High support from supervisors can help team members to reduce their emotional exhaustion, depersonalisation while increasing their selfefficacy and personal accomplishments. In addition, high support from supervisors can also increase members' personal accomplishment when faced with high demands of work (Gibson, Grey, \& Hasting, 2009). Supervisors also have an important role in promoting the creativity of team members through recognition, support and feedback. Kim, Hon and Lee (2010) found that the proactive behaviour of employees helped them to develop a better sense of creativity and this was found to be strongly enhanced by high supervisor support. At the organisational level, supervisor support was found to be a representative of organisational support (Eisenberger et al., 2002). Employees perceived supervisors as an organisational agent, especially those who were favoured by the organisations. This then leads to lower turnover rate. Organisational support becomes less important to turnover rate when supervisor support is high (Maertz Jr, Griffeth, Campbell, \& Allen, 2007). Similar findings were reported by DeConinck and Johnson (2009) who found that supervisor support can be an indirect predictor of turnover intention. Better supervisor support not only produces a higher perceived organisational support but also leads to employees' higher performance. Combining these two factors can lower employees' intention to quit. Supervisor's support received by employees can cause the employees to have a sense of obligation to their supervisors, thereby increasing their intention to stay with, rather than leave, that organisation (Kalemci Tuzun \& Arzu Kalemci, 2012).

\section{Theoretical Framework and Hypotheses Development}

Based on previous literature, this study defines co-worker support and supervisor support as the perception of an employee that he/she is loved, cared for, valued, and admired by the other co-workers and their supervisors. In line with Beehr et al. (2000), Semmer et al. (2008), and Tews et al. (2013), this study classifies co-worker support and supervisor support into two different constructs - emotional and instrumental.

Emotional support refers to the availability of a person to listen sympathetically when an employee is having problems; it also refers to 
the person demonstrating a sense of caring and acceptance. Emotional support comprises: i) empathy, ii) social companionship, iii) encouragement, and iv) expressive support (Östberg \& Lennartsson, 2007; Scott et al., 2014; Chadwick \& Collins, 2015). First, empathy refers to the emotional expression that a co-worker or a supervisor shows his/ her understanding of or sharing the same feeling with an employee. Second, social companionship refers to the emotion shown by a coworker or supervisor in illustrating his/her love, trust and care for an employee. Social companionship also refers to a co-worker or supervisor's willingness in socialising with an employee. Third, encouragement refers to the emotional expression which a co-worker or supervisor admires and recognises as the value of other employees. Fourth, expressive support refers to the emotional expression which a co-worker or supervisor feels affection for other employees. Literature (Kang et al., 2015; Avci, 2017) has documented numerous cases where emotional support provided by either a co-worker or supervisor could cushion the stress effect experienced by an employee. Workers who are confronted with multiple work demands that can strain their coping capabilities were found to draw their emotional support from coworkers or supervisors as a way of preventing themselves from being overwhelmed by feelings of helplessness and the loss of self-esteem. They may seek counselling or they may vent their feelings to co-workers and supervisors. Based on these arguments, it is thus postulated that:

$\mathrm{H}_{1}$ : Co-worker's empathy support is negatively related to the intention to quit.

$\mathrm{H}_{2}$ : Co-worker's social companionship support is negatively related to the intention to quit.

$\mathrm{H}_{3}$ : Co-worker's encouragement support is negatively related to the intention to quit.

$\mathrm{H}_{4}$ : Co-worker's expressive support is negatively related to the intention to quit.

$\mathrm{H}_{5}$ : Supervisor's empathy support is negatively related to the intention to quit.

$\mathrm{H}_{6}$ : Supervisor's social companionship support is negatively related to the intention to quit.

$\mathrm{H}_{7}$ : Supervisor's encouragement support is negatively related to the intention to quit.

$\mathrm{H}_{8}$ : Supervisor's expressive support is negatively related to the intention to quit. 
The second construct, instrumental support, refers to the material assistance provided either by co-workers or supervisors in response to the specific needs of an employee, where necessary. Such assistance could be in terms of transportation, childcare or other tangible aids. Consistent with studies (Östberg \& Lennartsson, 2007; Scott et al., 2014; Chadwick \& Collins, 2015), instrumental support is further divided into three variables: work-related tangible support, work-related informational support and non-work-related support. The term, workrelated tangible support, is defined as the actual action that a co-worker or a supervisor takes in assisting other employees in performing their work-related activities. Work-related informational support is defined as the provision of knowledge that is useful for solving work-related problems such as guidance on the alternative course of action. Lastly, non-work-related support refers to the assistance provided by a coworker or a supervisor in helping other employees on matters that are not related to work such as providing childcare services. There is a considerable amount of empirical evidence supporting the relationship between instrumental support and intention to quit (Knani, Fournier, \& Biron, 2018; Skaalvik \& Skaalvik, 2017). These studies revealed that instrumental support can potentially reduce ambiguity and on the job demands as well as emotional exhaustion resulting from the competing demands of work and family commitments. Employees reporting higher levels of instrumental support were found to perceive higher levels of job satisfaction, which indirectly, led to lower levels of intention to quit. Based on these empirical works, it is hereby postulated that:

$\mathrm{H}_{9}$ : Co-worker's work-related tangible support is negatively related to intention to quit.

$\mathrm{H}_{10}$ : Co-worker's work-related informational support is negatively related to intention to quit.

$\mathrm{H}_{11}$ : Co-worker's non-work-related support is negatively related to intention to quit.

$\mathrm{H}_{12}$ : Supervisor's work-related tangible support is negatively related to intention to quit.

$\mathrm{H}_{13}$ : Supervisor's work-related informational support is negatively related to intention to quit.

$\mathrm{H}_{14}$ : Supervisor's non-work-related support is negatively related to intention to quit.

The variables and their relationships are depicted in Figure 1. 
Co-worker's emotional support

Empathy

Social companionship

Encouragement

Expressive support

Supervisor's emotional support

Empathy

Social Companionship

Encouragement

Expressive Support

Co-worker's instrumental support

Tangible support

Informational support

Non-work related support

Supervisor's instrumental support

Tangible support

Informational support

Non-work related support

$\mathrm{H}_{12}-\mathrm{H}_{14}$

Figure 1: Research Framework

\section{Research Methodology}

The constructs used in this study were taken from literature and then adapted to suit the context of this study. The items used to measure the constructs are depicted in the Appendix. This study employed a quantitative method. A questionnaire was designed to collect data from the target population which comprised employees working at the entry-level position in one of the biggest Food and Beverage (F\&B) business operators in Bangkok (it accounted for 50 per cent of the market share). The company was first identified and then contacted through a telephone call. An invitation letter and a copy of the questionnaire were emailed to the human resource manager to secure permission 
and support for conducting the survey in the organisation. The human resource manager of the participating organisation then requested its 600 entry-level employees to complete the survey, through supervisors and section heads. A cover letter to the questionnaire made it clear that the survey was voluntary and confidential and that no individual results would be made available to the organisation. To ensure confidentiality, all questionnaires were returned to the first author in a sealed envelope. The employees received an envelope containing the questionnaire, information about the study, instruction for questionnaire completion, and an assurance of confidentiality. Of the 600 questionnaires distributed, a total of 348 questionnaires were retrieved with 322 that were complete and usable for analysis (representing a response rate of 57.3 per cent).

Table 1 presents the descriptive statistics which highlight that majority or 68.4 per cent were females and 31.6 per cent were males. This is acceptable as evidently, there were more females than males working as entry-level employees (e.g. a waitress is more common than a waiter)

Table 1: Respondents' Characteristics

\begin{tabular}{lrr}
\hline Characteristic & Frequency & Percentage \\
\hline Gender & & \\
Male & 102 & 31.6 \\
Female & 220 & 68.4 \\
Age & & \\
15-24 & 204 & 63.3 \\
$25-45$ & 113 & 35.1 \\
Above 46 & 5 & 1.5 \\
Marital status & & \\
Single & 262 & 81.4 \\
Married or living as married & 60 & 18.6 \\
Education & 13 & 4.1 \\
Primary School & 157 & 48.7 \\
Secondary School & 94 & 29.3 \\
Vocational Degree & 57 & 17.7 \\
Bachelor Degree & 1 & 0.3 \\
Master Degree and above & & \\
Years of Service & 177 & 55.0 \\
Less than 1 year & 91 & 28.3 \\
1 to 3 years & 54 & 16.7 \\
More than 3 years & & \\
\hline
\end{tabular}


in the food and beverage organisations. More than half or 63.3 per cent of the respondents were younger than 24 years old while about half or 55.0 per cent were almost new workers, with less than one year with the company. Majority of the respondents had completed their secondary school or possess a vocational degree (78.0 per cent). Given this, the samples were broadly representative of the entry-level employees of a typical food and beverage company in Thailand.

\section{Results and Discussion}

Regression analysis was performed using the OLS regression to examine the impact of the emotional and instrumental support of co-workers and supervisors. As this study aims to determine whether the impact differs according to the age factor, the samples were divided into two age groups based on the respondents' age. Group 1 comprises those between 15 to 24 years old and they are deemed as young workers. Group 2 comprises those aged above 25 years old and they are considered as older workers.

\subsection{Co-worker's Support on Intention to Quit}

Table 2 presents the OLS regressions of the intention to quit for each component of the co-worker's support which include empathy, social companionship, encouragement and expressive support, tangible support, informational support, and non-work-related support. In this analysis, emotional support and instrumental support of supervisors as well as other demographic variables were controlled (by constructing the average of all components of each support).

Emotional effects, as indicated in Table 2, illustrate that only empathy appears to have a significant impact on the intention to quit, for both young and older workers. Hence, $\mathrm{H}_{2}, \mathrm{H}_{3}$ and $\mathrm{H}_{4}$ are rejected. While empathy was found to reduce older workers' intention to quit, empathy increased younger workers' likelihood to quit. This result suggests an acceptance of $\mathrm{H}_{1}$ only for older workers. These findings appear to contradict earlier studies (Scott et al., 2014; Chadwick \& Collins, 2015) which could be attributed to the fact that young workers in Thailand possess less empathic ability when compared to older workers. This is also evidenced by several studies such as Richter and Kunzmann (2011) who established that young people generally expressed less sympathy and were poorer in sharing the emotion of others. Van der Graaff et al. 
Table 2: OLS Regressions of Co-worker's Support on Intention to Quit

\begin{tabular}{lccc}
\hline & \multicolumn{3}{c}{ Intention to quit } \\
\cline { 2 - 4 } Independent variables & All samples & Age 15-24 & Age above 25 \\
\hline Co-worker's emotional support & & & \\
Empathy & $(0.026) 0.49$ & $(0.134) 1.96^{* *}$ & $(0.161)-1.97^{* *}$ \\
Social companionship & $(0.034) 0.92$ & $(0.066) 1.21$ & $(0.015) 0.22$ \\
Encouragement & $(0.020)-0.41$ & $(0.028)-0.48$ & $(0.036) 0.37$ \\
Expressive support & $(0.038) 0.76$ & $(0.034) 0.58$ & $(0.030)-0.28$ \\
Co-worker's instrumental support & & & \\
Tangible support & $(0.035)-0.75$ & $(0.092)-1.72^{*}$ & $(0.150) 1.41$ \\
Informational support & $(0.022) 0.43$ & $(0.033) 0.52$ & $(0.130)-1.29$ \\
Non-work-related support & $(0.084)-1.96^{* *}$ & $(0.114)-2.32^{* *}$ & $(0.030)-0.32$ \\
Control variables & & & \\
Supervisor's emotional support & $(0.138)-2.14^{* *}$ & $(0.182)-2.50^{* *}$ & $(0.082)-0.57$ \\
Supervisor's instrumental support & $(0.070)-1.00$ & $(0.004) 0.05$ & $(0.128)-1.08$ \\
Age & $(0.007)-1.40$ & $(0.019)-0.74$ & $(0.004)-0.54$ \\
Gender & $(0.038)-0.59$ & $(0.031)-0.39$ & $(0.047) 0.43$ \\
Marital status & $(0.068) 1.26$ & $(0.130) 1.17$ & $(0.053) 0.77$ \\
Education & $(0.020) 0.65$ & $(0.053) 1.16$ & $(0.003) 0.07$ \\
Years of service & $(0.0002) 0.22$ & $(0.0014) 0.57$ & $(0.002) 1.60$ \\
\hline R-square & 0.13 & 0.12 & 0.26 \\
Number of observations & 322 & 197 & 96 \\
\hline
\end{tabular}

Note: All regressions use White heteroskedasticity-consistent standard errors. ${ }^{* * *}$, ** and * indicate 99, 95 and 90 per cent of confidence level. Standard errors in parentheses.

(2014) also detected that teenagers were still at the stage of developing their empathic ability while O'Brien, Konrath, Grühn and Hagen (2013) reported an inverted-U-shape relationship between age and empathic concern (an emotional component of empathy) and perspective taking (a cognitive component of empathy). Based on this, it is deduced that young workers have less emphatic ability (both giving and receiving) and so they could misinterpret the empathic concern of their co-workers as an insult, inadvertently increasing their intention to quit. It is also surprising to note that other emotional supports (social companionship, encouragement and expressive support) from co-workers did not help to reduce young workers' intention to quit even though they came from a collectivist and feminine country. It is possible that these young workers, 
being in the developmental stage of their emotional and social skills, were still not used to others' concerns. This outcome has been linked to extensive evidence which showed that young workers may possess less empathic abilities when compared to older workers. The same might be said for emotional and social skills which include empathic concerns.

With regard to co-worker's instrumental support, this study found that only work-related tangible support and non-work-related support of co-workers have a statistically significant effect in reducing employees' intention to quit but it was only significant among young workers. Therefore, $\mathrm{H}_{9}$ and $\mathrm{H}_{11}$ are supported for the young workers only. With exception to the empathy support, this study has also demonstrated that co-worker's support does not have a significant impact on older workers' intention to quit. This phenomenon could be related to cultural factors. In a culture of high power-distance such as Thailand, senior people are supposed to be respected by the juniors and they are supposed to be the ones providing advice and support to the younger people and not vice versa. In this situation, older workers may have felt "intimidated" or "insulted" when receiving various kinds of support from their co-workers (all co-worker support except empathy has no impact on reducing the intention to quit of older workers) because most of their co-workers were younger (63 per cent of our respondents were aged between 15 to 24 years). To the older employees, accepting support from co-workers who were younger, may depict their incompetence and their lack of ability or independence (Ng \& Sorensen, 2008). Among the younger workers in this study, many tend to perceive their current jobs as temporary ones. This seems inevitable because young workers, those below 25 years old, have a high tendency to go back to school or to look for better job prospects in the near future ( $\mathrm{Lu}, \mathrm{Lu}$, Gursoy \& Neale, 2016). For these young workers, the current job is only a temporary source of income to help them with their daily expenses or educational expenses. Since the current job is perceived to be a temporary one, they were thus less motivated into paying full attention in advancing their current job (i.e. no motivation to be promoted from a waitress to a supervisor). Under this circumstance, they need not care much about work-related informational support provided by co-workers. It is deduced that this could be the reason why the co-workers' support did not influence the young workers' intention to quit. Moreover, non-work related support was more about building pleasant relationships with co-workers (who might become their friends or life partners after they leave the company) and not about advancing 
their current job. Thus, it is further deduced that this could be the cause why non-work related support did not help to reduce young workers' intention to quit in this study.

\subsection{Supervisor's Support on Intention to Quit}

Table 3 depicts the results of the OLS regressions of the supervisor's support on the intention to quit. In this analysis, the emotional and instrumental supports of the co-workers as well as other demographic variables were controlled (by constructing the average of all components of each support).

Table 3: OLS Regressions of Supervisor's Support on Intention to Quit

\begin{tabular}{llcl}
\hline & \multicolumn{3}{c}{ Intention to quit } \\
\cline { 2 - 4 } Independent variables & All samples & Age 15-24 & Age above 25 \\
\hline Supervisor's emotional support & & & \\
Empathy & $(0.031)-0.57$ & $(0.019) 0.32$ & $(0.056)-0.56$ \\
Social companionship & $(0.031)-0.93$ & $(0.078)-1.77^{*}$ & $(0.040) 0.63$ \\
Encouragement & $(0.132)-2.11^{* *}$ & $(0.150)-2.11^{* *}$ & $(0.196)-1.78^{*}$ \\
Expressive support & $(0.056) 0.99$ & $(0.054) 0.88$ & $(0.071) 0.71$ \\
Supervisor's instrumental support & & & \\
Tangible support & $(0.064)-1.13$ & $(0.032) 0.46$ & $(0.260)-2.54^{* *}$ \\
Informational support & $(0.071) 1.48$ & $(0.013) 0.19$ & $(0.270) 2.90^{* *}$ \\
Non-work-related support & $(0.079)-1.95^{*}$ & $(0.075)-1.52$ & $(0.061)-0.64$ \\
Control variables & & & \\
Co-worker's emotional support & $(0.083) 1.55$ & $(0.212) 3.46^{* * *}$ & $(0.112)-1.07$ \\
Co-worker's instrumental support & $(0.107)-2.03^{* *}$ & $(0.179)-3.17^{* *}$ & $(0.050)-0.58$ \\
Age & $(0.008)-1.55$ & $(0.009)-0.37$ & $(0.002)-0.35$ \\
Gender & $(0.046)-0.71$ & $(0.008)-0.10$ & $(0.011) 0.05$ \\
Marital status & $(0.075) 1.43$ & $(0.123) 1.28$ & $(0.099) 1.45$ \\
Education & $(0.020) 0.66$ & $(0.076) 1.26$ & $(0.004) 0.08$ \\
Years of service & $(0.000) 0.21$ & $(0.002) 0.59$ & $(0.001) 0.82$ \\
\hline R-square & 0.13 & 0.12 & 0.32 \\
Number of observations & 322 & 197 & 96 \\
\hline & & & \\
\hline
\end{tabular}

Note: All regressions use White heteroskedasticity-consistent standard errors. ***, ** and * indicate 99, 95 and 90 per cent of confidence level. Standard errors in parentheses. 
As depicted in the table, only encouragement under supervisor's emotional support carries a statistically significant effect on the intention to quit, thereby supporting $\mathrm{H}_{7}$. This finding is in line with Östberg and Lennartsson (2007). Based on characteristics of the femininity culture, workers should be supportive, kind and generous but at the same time, in a power distance culture such as Thailand, supervisors are expected to "keep their distance" from other employees. In the Thai culture, good supervisors are leaders (Phornprapha, \& Chansrichawla, 2007) and workers may perceive their supervisors as big brothers or sisters but not "friends" of equal status. There is always some distance between supervisors and subordinates. Therefore, when supervisors try to be friendly with subordinates, their action may cause discomfort among their subordinates or even threaten them. This could explain why only encouragement, but not others, seems to have a strong effect in reducing workers' intention to quit.

Thus, this study has uncovered that supervisor's instrumental support, in terms of tangible and informational support, only influenced older workers' intention to quit. While supervisor's tangible workrelated support has a negative impact on workers' intention to quit, supervisor's informational support positively influenced workers' intention to quit. This finding supports $\mathrm{H}_{12}$ in the context of the older workers who may be facing work-family conflict more, as compared to young workers. In that regard, they valued the supervisor's tangible support in diminishing stress such as flexitime and compressed workweeks ( $\mathrm{Ng}$ \& Sorensen, 2008). Similarly, as the respondents of this study consist of entry-level workers, the younger workers may not see the supervisor's instrumental support as important factors for them to stay in the company. As young workers who also belonged to the Millennial group, they were more likely to consider the entry-level position as a short-term job and not a career which they can achieve selfaccomplishment. Due to this, they were expected to exhibit a lesser level of work engagement and work commitment. Hence, they may not value the supervisor's support as much as the older workers. The conflicting findings may also be attributed to the fact that older workers were relatively similar in age with their supervisors. Therefore, receiving informational support could be interpreted as an "insult" as it could be perceived as supervisors thinking that older workers do not know how to do their job. This may therefore, cause a higher intention to quit among older workers. 


\section{Implications and Conclusion}

Finding ways to retain young workers will be even more important for Thailand in the near future as the number of workers will be dropping sharply due to rapid demographic transitions. Taking this crucial issue into consideration, this paper has examined the influence of co-worker's and supervisor's support on young workers' intention to quit in the food and beverage $(\mathrm{F} \& \mathrm{~B})$ business in Thailand. While extensive literature has examined the influence of co-worker's and supervisor's support on employees' intention to quit, most had focused on the western context. However, due to cultural differences, the effects between the West and Asia may be different. The findings of this study have demonstrated that different contexts and environments may be the reason causing the deviation in results. Based on a sample of 322 employees who worked in a large F\&B company in Thailand, our results had indicated that the support noted by western countries as effective instruments in reducing employees' intention to quit were ineffective in our study which noted that none of the components of the co-worker emotional support, except empathy, affected all the workers' intention to quit. In the case of the co-worker's instrumental support, only the non-work-related support reduced workers' intention to quit and this effect only occurred among the young workers. In the case of the supervisor's support, our study has revealed that only encouragement reduced workers' intention to quit while supervisors' tangible work-related support reduced only the older workers' intention to quit. Furthermore, some of these supports even carried an opposite effect on the workers' intention to quit. For instance, our study found that empathy from co-workers increased the young workers' intention to quit while supervisor's informational support increased the older workers' intention to quit. Besides the cultural effects, the generational factor gathered from this study also offers a new perspective of the intention to quit. Future studies can focus more on the effect of demographic differences so as to gain more insights into this area of research.

The empirical evidence drawn from this study also adds to the managerial contributions. First, companies in the F\&B industry need to be aware that age plays an important role in employees' perception of co-worker and supervisor support in Thailand. Not all individuals will actively seek support. Some individuals may even find social support intervention to be counterproductive. Therefore, it is proposed that the support needs to be adjusted so as to ensure its suitability across 
organisations, particularly among different age groups. Companies also need to provide multiple types of support for different kinds of workers by ensuring that these workers have access to voluntary support since this can curb unintended negative consequences. With this information, organisations should adjust their corporate culture, communication strategy, including their human resource management strategies in order to make their company policies more efficient, thereby bettering employee satisfaction and reducing turnover rates. The findings of this study also specifically suggest that managers need to focus on enhancing the non-work-related support of co-workers and to increase encouragement from supervisors in order to retain young workers who require less or no empathy support from their co-workers. As for the older workers, managers of organisations need to focus on increasing empathy among co-workers such that supervisors provide encouragement and tangible support to the team members since this may be considered as decreasing supervisors' informational support. Alternatively, supervisors could adjust their approach in providing information by accommodating to the cultural contexts involved. The findings of this study also suggest that there is an opportunity for organisations to impact large numbers of employees through different types of social supports provided by co-workers and supervisors.

As discussed earlier, cultural values (high power distance, collectivism and femininity) assume important roles in influencing the perception and needs of both young and older workers who require emotional and instrumental supports that can impact their intention to quit. The relationship between co-worker and supervisor support and young workers' intention to quit is not a linear relationship. In fact, it is a complex relationship determined by cultural values and job characteristics. Organisations should therefore make careful considerations before implementing co-worker and supervisor support. This can be accomplished by taking into account their age, their perception of the job, and cultural values such as high-power distance, collectivism and femininity. In the Thai culture, collectivism and femininity may generally influence workers in organisations to value good relationship with co-workers and supervisors by seeking their support. Nevertheless, organisations should also try to understand whether these young workers perceived their job as a permanent or temporary one. If they intend to work on a temporary basis, then organisations should not provide co-worker and supervisor support as these do not help to retain them. Conversely, organisations should craft other strategies which has 
a likelihood of changing their employees' attitudes. This is particularly important for the F\&B industry in Thailand which has been confronted with a high turnover rate of young employees at the entry level in the past few years. The F\&B industry needs to learn how to create a work environment and human resource practices that can inspire and retain employees of different age groups appropriately.

Although this study only focused on the F\&B company located in Thailand, it is believed that our findings can also be applied and utilised across different industries with similar settings and/or different countries with similar cultures, especially ASEAN countries. Moreover, workers' perceptions toward cultural values, job characteristics, and the influence of co-worker and supervisor support on the intention to quit may vary, as shown in this study, but that is the nature of this kind of research. In addition, the questionnaire administered in this study was not designed to match or identify any supervisors with their subordinates and vice versa. Therefore, future studies could focus on these gaps so as to shed more light with more comprehensive evidences.

\section{References}

Alén, E., Banerjee, B., \& Gupta, B. (2017). Transformational leadership and creative performance: A dyadic analysis of salespeople and their supervisors. Asian Journal of Business and Accounting, 10(1), 201-233.

Arshad, M., \& Bhat, S.A. (2013). Youth in a globalizing world. International Journal of Physical and Social Sciences, 3(6), 140-153.

Avci, N. (2017). The relationship between coworker supports, quality of work life and wellbeing: An empirical study of hotel employees. International Journal of Management Economics and Business, 13(3), 577-590. http://dx.doi. org/10.17130/ijmeb.2017331328

Babin, B.J., \& Boles, J.S. (1996). The effects of perceived co-worker involvement and supervisor support on service provider role stress, performance and job satisfaction. Journal of Retailing, 72(1), 57-75. http://dx.doi.org/10.1016/ S0022-4359(96)90005-6

Barak, M.E.M., Nissly, J.A., \& Levin, A. (2001). Antecedents to retention and turnover among child welfare, social work, and other human service employees: What can we learn from past research? A review and metanalysis. Social Service Review, 75(4), 625-661. http://dx.doi.org/10.1086/323166

Bateman, G. (2009). Employee perceptions of co-worker support and its effect on job satisfaction, work stress and intention to quit (Doctorol thesis, University of Canterbury, New Zealand). Retrieved from https://ir.canterbury.ac.nz/ handle/10092/4050 
Beehr, T.A., Jex, S.M., Stacy, B.A., \& Murray, M.A. (2000). Work stressors and co-worker support as predictors of individual strain and job performance. Journal of Organizational Behavior, 21(4), 391-405. http://dx.doi.org/ 10.1002/(SICI)1099-1379(200006)21:4<391::AID-JOB15>3.0.CO;2-9

Beehr, T.A., \& McGrath, J.E. (1992). Social support, occupational stress and anxiety. Anxiety, Stress, and Coping, 5(1), 7-19. http://dx.doi.org/10.1080/ 10615809208250484

Bureau of Labour Statistics (2015). Employment by industry. Retrieved from https://www.bls.gov/opub/ted/2016/employment-by-industry-1910and-2015.htm

Chadwick, K.A., \& Collins, P.A. (2015). Examining the relationship between social support availability, urban center size, and self-perceived mental health of recent immigrants to Canada: A mixed-methods analysis. Social Science \& Medicine, 128(March), 220-230. http://dx.doi.org/10.1016/ j.socscimed.2015.01.036

Chiaburu, D.S., \& Harrison, D.A. (2008). Do peers make the place? Conceptual synthesis and meta-analysis of coworker effects on perceptions, attitudes, OCBs, and performance. Journal of Applied Psychology, 93(5), 1082-1103. http://dx.doi.org/10.1037/0021-9010.93.5.1082

Cho, S., Johanson, M.M., \& Guchait, P. (2009). Employees intent to leave: A comparison of determinants of intent to leave versus intent to stay. International Journal of Hospitality Management, 28(3), 374-381. http:/ / dx.doi. org/ 10.1016/j.ijhm.2008.10.007

Cobb, S. (1976). Social support as a moderator of life stress. Psychosomatic Medicine, 38(5), 300-314. http:/ / dx.doi.org/10.1097/00006842-197609000-00003

Cohen, S. (2004). Social relationships and health. American Psychologist, 59(8), 676-684. http://dx.doi.org/10.1037/0003-066X.59.8.676

Cohen, S., \& Hoberman, H.M. (1983). Positive events and social supports as buffers of life change stress. Journal of Applied Social Psychology, 13(2), 99125. http://dx.doi.org/10.1111/j.1559-1816.1983.tb02325.x

DeConinck, J.B., \& Johnson, J.T. (2009). The effects of perceived supervisor support, perceived organizational support, and organizational justice on turnover among salespeople. Journal of Personal Selling $\mathcal{E}$ Sales Management, 29(4), 333-350.

Ducharme, L.J., Knudsen, H.K., \& Roman, P.M. (2007). Emotional exhaustion and turnover intention in human service occupations: The protective role of coworker support. Sociological Spectrum, 28(1), 81-104. http://dx.doi. org/10.1080/02732170701675268

Eisenberger, R., Stinglhamber, F., Vandenberghe, C., Sucharski, I.L., \& Rhoades, L. (2002). Perceived supervisor support: Contributions to perceived organizational support and employee retention. Journal of Applied Psychology, 87(3), 565-573. http://dx.doi.org/10.1037/0021-9010.87.3.565

Felps, W., Mitchell, T.R., Hekman, D.R., Lee, T.W., Holtom, B.C., \& Harman, W.S. (2009). Turnover contagion: How coworkers' job embeddedness and 
job search behaviors influence quitting. Academy of Management Journal, 52(3), 545-561. http:/ / dx.doi.org/10.5465/amj.2009.41331075

Firth, L., Mellor, D.J., Moore, K.A., \& Loquet, C. (2004). How can managers reduce employee intention to quit? Journal of Managerial Psychology, 19(2), 170-187. http:/ / dx.doi.org/10.1108/02683940410526127

Frone, M.R., Russell, M., \& Cooper, M.L. (1997). Relation of work-family conflict to health outcomes: A four-year longitudinal study of employed parents. Journal of Occupational and Organizational Psychology, 70(4), 325-335. http:/ / dx.doi.org/10.1111/j.2044-8325.1997.tb00652.x

Gabčanová, I.V.E.T.A. (2011). The employees - the most important asset in the organizations. Human Resources Management \& Ergonomics, 5(1), 30-33.

Gibson, J.A., Grey, I.M, Hasting, R.P. (2009). Supervisor support as a predictor of burnout and therapeutic self-efficacy in therapists working in ABA schools. Journal of Autism and Developmental Disorders, 39(7), 1024-1030. http://doi. org/10.1007/s10803-009-0709-4

Glazer, S. (2006). Social support across cultures. International Journal of Intercultural Relations, 30(5), 605-622. http://dx.doi.org/10.1016/j.ijintrel. 2005.01.013

Glomb, T.M., \& Tews, M.J. (2004). Emotional labor: A conceptualization and scale development. Journal of Vocational Behavior, 64(1), 1-23. http:/ / dx.doi. org/10.1016/S0001-8791(03)00038-1

GRI (2002). Sustainability reporting guidelines. Boston: Global Reporting Initiative.

Hammer, L.B., Kossek, E.E., Yragui, N.L., Bodner, T.E., \& Hanson, G.C. (2009). Development and validation of a multidimensional measure of family supportive supervisor behaviors (FSSB). Journal of Management, 35(4), 837856. http:/ / dx.doi.org/10.1177/0149206308328510

Hausknecht, J.P., Rodda, J., \& Howard, M.J. (2009). Targeted employee retention: Performance-based and job-related differences in reported reasons for staying. Human Resource Management, 48(2), 269-288. http://dx.doi. org/10.1002/hrm.20279

Hofstede, G. (2001). Culture's consequences: Comparing values, behaviours, institutions and organisations across nations. Thousand Oaks, CA: Sage Publications.

International Labour Organisation. (2010). Global employment trends for youth: August 2010: Special issue on the impact of the global economic crisis on youth. Geneva, Switzerland: Author.

Kalemci Tuzun, I., \& Arzu Kalemci, R. (2012). Organizational and supervisory support in relation to employee turnover intentions. Journal of Managerial Psychology, 27(5), 518-534. http://dx.doi.org/10.1108/02683941211235418

Kang, H.J., Gatling, A., \& Kim, J. (2015). The impact of supervisory support on organizational commitment, career satisfaction, and turnover intention for hospitality frontline employees. Journal of Human Resources in Hospitality $\mathcal{E}$ Tourism, 14(1), 68-89. http:/ / dx.doi.org/10.1080/15332845.2014.904176

Kim, T-Y., Hon, A.H.Y., Lee, D-R. (2010). Proactive personality and employee creativity: The effects of job creativity requirement and supervisor 
support for creativity. Creative Research Journal, 22(1), 37-45. http://dx.doi. org/10.1080/10400410903579536

Knani, M., Fournier, P-S., \& Biron, C. (2018). Psychosocial risks, burnout and intention to quit following the introduction of new software at work. Work, 60(1), 95-104. http://dx.doi.org/10.3233/WOR-182714

Kundu, S.C., \& Gahlawat, N. (2015). Socially responsible HR practices and employees' intention to quit: The mediating role of job satisfaction. Human Resource Development International, 18(4), 387-406. http://dx.doi.org/10. 1080/13678868.2015.1056500

Kwon, H.W. (2017). A social embeddedness perspective on turnover intention: The role of informal networks and social identity evidence from South Korea. Public Personnel Management, 46(3), 263-287. http://dx.doi.org/ $10.1177 / 0091026017717459$

Limpanitgul, T., Robson, M.J., Gould-Williams, J., Lertthaitrakul, W. (2013). Effects of co-worker support and customer cooperation on service employee attitudes and behaviour: Empirical evidence from the airline industry. Journal of Hospitality and Tourism Management, 20, 23-33 http:// dx.doi.org/10.1016/j.jhtm.2013.05.004

Lu, L., Lu, A.C.C., Gursoy, D., \& Neale, N.R. (2016). Work engagement, job satisfaction, and turnover intentions: A comparison between supervisors and line-level employees. International Journal of Contemporary Hospitality Management, 28(4), 737-761. http://dx.doi.org/10.1108/IJCHM-07-2014-0360

Malecki, C.K., \& Demaray, M.K. (2003). What type of support do they need? Investigating student adjustment as related to emotional, informational, appraisal, and instrumental support. School Psychology Quarterly, 18(3), 231252. http:// dx.doi.org/10.1521/scpq.18.3.231.22576

Maertz Jr, C.P., Griffeth, R.W., Campbell, N.S., \& Allen, D.G. (2007). The effects of perceived organizational support and perceived supervisor support on employee turnover. Journal of Organizational Behavior, 28(8), 1059-1075. http://dx.doi.org/10.1002/job.472

Mathieu, C., Fabi, B., Lacoursière, R., \& Raymond, L. (2016). The role of supervisory behavior, job satisfaction and organizational commitment on employee turnover. Journal of Management \& Organization, 22(1), 113-129. http://dx.doi.org/10.1017/jmo.2015.25

Mutsuddi, I., \& Sinha, C. (2017). Social antecedents and employee intention to stay in selected IT organizations: A study in national capital region of Delhi. FIIB Business Review, 6(1), 45-55. http://dx.doi.org/10.1177/ 2455265820170107

National Food Institute. (2018). Food industry in Thailand. Retrieved from https://www.paih.gov.pl/files/?id_plik=20603

Newman, A., Thanacoody R., \& Hui W. (2011). The effects of perceived organizational support, perceived supervisor support and intra-organizational network resources on turnover intentions: A study of Chinese employees 
in multinational enterprises. Personnel Review, 41(1), 56-72. http://dx.doi. org/10.1108/00483481211189947

Ng, T.W.H., \& Sorensen, K.L. (2008). Toward a further understanding of the relationships between perceptions of support and work attitudes: A metaanalysis. Group \& Organization Management, 33(3), 243-268. http://dx.doi. org/ 10.1177/1059601107313307

O’Brien, E., Konrath, S.H., Grühn, D., \& Hagen, A.L. (2013). Empathic concern and perspective taking: Linear and quadratic effects of age across the adult life span. The Journals of Gerontology Series B: Psychological Sciences and Social Sciences, 68(2), 168-175. http://dx.doi.org/10.1093/geronb/gbs055

Östberg, V., \& Lennartsson, C. (2007). Getting by with a little help: The importance of various types of social support for health problems. Scandinavian Journal of Public Health, 35(2), 197-204. http://dx.doi.org/ 10.1080/14034940600813032

Phornprapha, S., \& Chansrichawla, S. (2007). Leadership-supported mentoring: The key to enhancing organisational commitment and retaining newcomers. International Journal of Management and Decision Making, 8(2-4), 394425. http:/ / dx.doi.org/10.1504/IJMDM.2007.012731

Presbitero, A., Roxas, B., \& Chadee, D. (2016). Looking beyond HRM practices in enhancing employee retention in BPOs: Focus on employee-organisation value fit. The International Journal of Human Resource Management, 27(6), 635652. http://dx.doi.org/10.1080/09585192.2015.1035306

Price, J.L. (2001). Reflections on the determinants of voluntary turnover. International Journal of Manpower, 22(7), 600-624. http://dx.doi.org/10.1108/ EUM0000000006233

Radford, K., Shacklock, K.H., \& Bradley, G.L. (2012). Battle of the decades: Generational differences in the retention of Australian aged care employees. Paper presented at the 11th National Conference of Emerging Researchers in Ageing, Brisbane, Australia. Retrieved from www.uq.edu.au/bluecare/ era-2012

Richter, D., \& Kunzmann, U. (2011). Age differences in three facets of empathy: performance-based evidence. Psychology and Aging, 26(1), 60-70. http:// dx.doi.org/10.1037/a0021138

Scott, K.L., Zagenczyk, T.J., Schippers, M., Purvis, R.L., \& Cruz, K.S. (2014). Co-worker exclusion and employee outcomes: An investigation of the moderating roles of perceived organizational and social support. Journal of Management Studies, 51(8), 1235-1256. http://dx.doi.org/10.1111/joms. 12099

Semmer, N.K., Elfering, A., Jacobshagen, N., Perrot, T., Beehr, T.A., \& Boos, N. (2008). The emotional meaning of instrumental social support. International Journal of Stress Management, 15(3), 235-251. http://dx.doi. org/10.1037/1072-5245.15.3.235

Settoon, R.P., \& Mossholder, K.W. (2002). Relationship quality and relationship context as antecedents of person- and task-focused interpersonal citizen- 
ship behavior. Journal of Applied Psychology, 87(2), 255-267. http://dx.doi. org/10.1037//0021-9010.87.2.255

Shacklock, K., \& Brunetto, Y. (2011). A model of older workers' intentions to continue working. Personnel Review, 40(2), 252-274. http://dx.doi.org/ 10.1108/00483481111106110

Sherbourne, C.D., \& Stewart, A.L. (1991). The MOS social support survey. Social Science \& Medicine, 32(6), 705-714. http://dx.doi.org/10.1016/02779536(91)90150-B

Sheridan, J.E. (1992). Organizational culture and employee retention. The Academy of Management Journal, 35(5), 1036-1056. http://dx.doi. org/10.5465/256539

Skaalvik, E.M., \& Skaalvik, S. (2017). Still motivated to teach? A study of school context variables, stress and job satisfaction among teachers in senior high school. Social Psychology of Education, 20(1), 15-37. http://dx.doi.org/ 10.1007/s11218-016-9363-9

Steiner, A., \& Atterton, J. (2014). The contribution of rural businesses to community resilience. Local Economy, 29(3), 228-244. http://dx.doi.org/ $10.1177 / 0269094214528853$

Supeli, A., \& Creed, P.A. (2016). The longitudinal relationship between protean career orientation and job satisfaction, organizational commitment, and intention-to-quit. Journal of Career Development, 43(1), 66-80. http://dx.doi. org/10.1177/0894845315581686

Tett, R.P., \& Meyer, J.P. (1993). Job satisfaction, organizational commitment, turnover intention, and turnover: Path analyses based on meta-analytic findings. Personnel Psychology, 46(2), 259-293. http://dx.doi.org/10.1111/ j.1744-6570.1993.tb00874.x

Tews, M.J., Michel, J.W., \& Ellingson, J.E. (2013). The impact of coworker support on employee turnover in the hospitality industry. Group $\mathcal{E}$ Organization Management, 38(5), 630-653. http://dx.doi.org/10.1177/ 1059601113503039

United Nations (2015). World Population Prospects: The 2015 Revision. New York: Economic and Social Affairs, Population Division.

Van der Graaff, J., Branje, S., De Wied, M., Hawk, S., Van Lier, P., \& Meeus, W. (2014). Perspective taking and empathic concern in adolescence: Gender differences in developmental changes. Developmental Psychology, 50(3), 881888. http://dx.doi.org/10.1037/a0034325

Yoon, J., \& Thye, S. (2000). Supervisor support in the work place: Legitimacy and positive affectivity, The Journal of Social Psychology, 140(3), 295-316. http:/ / dx.doi.org/10.1080/00224540009600472 
Appendix

\begin{tabular}{|c|c|c|c|}
\hline Constructs & Variables & $\begin{array}{l}\text { Measurement using a five-point } \\
\text { Likert-type scale }\end{array}$ & References \\
\hline \multirow[t]{4}{*}{$\begin{array}{l}\text { Emotional } \\
\text { support }\end{array}$} & Empathy & $\begin{array}{l}\text { 1) My co-workers/supervisor } \\
\text { made an extra effort to } \\
\text { understand my problems } \\
\text { 2) My co-workers/supervisor } \\
\text { understand my problems } \\
\text { 3) My co-workers/supervisor } \\
\text { took a personal interest in me }\end{array}$ & $\begin{array}{l}\text { Settoon and } \\
\text { Mossholder } \\
\text { (2002); } \\
\text { Tew et al. (2013) }\end{array}$ \\
\hline & $\begin{array}{l}\text { Social } \\
\text { companion- } \\
\text { ship }\end{array}$ & $\begin{array}{l}\text { 1) My co-workers/supervisor } \\
\text { threw a birthday party for me } \\
\text { 2) My co-workers/supervisor } \\
\text { invited me to do things (e.g. } \\
\text { going out for lunch or playing } \\
\text { sports) with them }\end{array}$ & $\begin{array}{l}\text { Cohen and } \\
\text { Hoberman } \\
(1983)\end{array}$ \\
\hline & $\begin{array}{l}\text { Encourage- } \\
\text { ment }\end{array}$ & $\begin{array}{l}\text { 1) My co-workers/supervisor } \\
\text { took pride in my } \\
\text { accomplishments } \\
\text { 2) My co-workers/supervisor tried } \\
\text { to cheer me up when I'm having } \\
\text { a bad day }\end{array}$ & $\begin{array}{l}\text { Cohen and } \\
\text { Hoberman } \\
\text { (1983); } \\
\text { Tew et al. (2013) }\end{array}$ \\
\hline & $\begin{array}{l}\text { Expressive } \\
\text { support }\end{array}$ & $\begin{array}{l}\text { 1) My co-workers/supervisor } \\
\text { listened to my problems in } \\
\text { juggling work and non-work life } \\
\text { 2) My co-workers/supervisor } \\
\text { listened to me when I had to } \\
\text { get something off my chest } \\
\text { 3) My co-workers/supervisor took } \\
\text { time to listen to my problems } \\
\text { and worries }\end{array}$ & $\begin{array}{l}\text { Settoon and } \\
\text { Mossholder } \\
\text { (2002); } \\
\text { Hammer, } \\
\text { Kossek, Yragui, } \\
\text { Bodner and } \\
\text { Hanson (2009) }\end{array}$ \\
\hline $\begin{array}{l}\text { Instrumental } \\
\text { support }\end{array}$ & $\begin{array}{l}\text { Tangible } \\
\text { support }\end{array}$ & $\begin{array}{l}\text { 1) My co-workers/supervisor } \\
\text { helped me with difficult } \\
\text { assignments, even when } \\
\text { assistance is not directly } \\
\text { requested } \\
\text { 2) My co-workers/supervisor } \\
\text { assisted me with heavy } \\
\text { workloads even though it is } \\
\text { not part of job }\end{array}$ & $\begin{array}{l}\text { Settoon and } \\
\text { Mossholder } \\
\text { (2002); } \\
\text { Tew et al. (2013) }\end{array}$ \\
\hline
\end{tabular}




\begin{tabular}{|c|c|c|c|}
\hline Constructs & Variables & $\begin{array}{l}\text { Measurement using a five-point } \\
\text { Likert-type scale }\end{array}$ & References \\
\hline & & $\begin{array}{l}\text { 3) My co-workers/supervisor } \\
\text { helped me when I am running } \\
\text { behind my work }\end{array}$ & \\
\hline & $\begin{array}{l}\text { Informa- } \\
\text { tional } \\
\text { support }\end{array}$ & $\begin{array}{l}\text { 1) My co-workers/supervisor took } \\
\text { time to explain regulations or } \\
\text { procedures to me when I have } \\
\text { questions } \\
\text { 2) My co-workers/supervisor gave } \\
\text { me information to help me } \\
\text { understand a situation } \\
\text { 3) My co-workers/supervisor } \\
\text { always shared work-related } \\
\text { knowledge to me when I need it } \\
\text { to perform my job }\end{array}$ & $\begin{array}{l}\text { Sherbourne and } \\
\text { Stewart (1991); } \\
\text { Settoon and } \\
\text { Mossholder } \\
\text { (2002) }\end{array}$ \\
\hline & $\begin{array}{l}\text { Non-work- } \\
\text { related } \\
\text { support }\end{array}$ & $\begin{array}{l}\text { 1) My co-workers/supervisor } \\
\text { helped me with work when I } \\
\text { have been absent } \\
\text { 2) If I needed an emergency loan } \\
\text { of THB1,000 (about } \$ 30 \text { ), I could } \\
\text { get it from my co-workers/ } \\
\text { supervisor } \\
\text { 3) My co-workers/supervisor took } \\
\text { me to doctor when I was sick }\end{array}$ & $\begin{array}{l}\text { Cohen and } \\
\text { Hoberman } \\
(1983) ; \\
\text { Settoon and } \\
\text { Mossholder } \\
(2002)\end{array}$ \\
\hline
\end{tabular}

